\section{Books About Books}

The Hand-Produced Book. By David Diringer. New York, Philosophical Library, 1953. \$15.

Von Buechern und Bibliotheken (Of Books and Libraries). By Richard Mummendey. Bonn, Buchgemeinde, I950. DM r 4.50 (c. \$3.75)

Die Illustratierten Vogel-Bücher, ihre Geschichte und Bibliographie (Illustrated Bird Books, their History and Bibliography). By Clauss Nissen. Stuttgart, Hiersemann, 1953. 222 p. DM 6o (c. \$15.)

Fine Bird Books 1700-1900. By Sacheverell Sitwell, Handasyde Buchanan and James Fisher. London and New York, Collins \& Van Nostrand, 1953.

Two observations of general interest can be made about the books to be discussed here. One is the fact that our knowledge of the history of the book, slowly but surely, is taking on global proportions. We are freeing ourselves from a perspective traditionally limited to the western civilization. Leading scholars are seeing more and more of the contributions of the many separate cultures that have contributed to the growth of the book as a vital instrument of intellectual growth and they are beginning to trace their mutual interaction.

The other observation is the growing volume of sound scholarship contributed by American archaeologists, paleographers, art historians and students of graphic communication.

David Diringer's The Hand-Produced Book is a beautiful example of widening horizons. The picture that emerges before the reader of this astonishingly rich and varied collection of material from all over the world is the most complete one ever painted of the birth and rise of the book from early beginnings to the advent of printing. It has excellent illustrations. The work is conceived as a companion volume to the same author's The Alphabet, and is to be followed by future studies on binding and illumination.

Certain defects of The Hand-Produced $B o o k$ cannot be overlooked. It suffers throughout from the lack of a clear definition of the book as a specific combination of function and form. As a result the thread of continuity is often submerged in general discussions of other forms of communication. Also, it is neither quite a supplement to The Alphabet nor yet really an independent work, as becomes evident to anyone who reads it without a copy of the other work at hand to refer to. Too often, developments are dealt with in subdivisions instead of as part of the main story, which therefore becomes hard to trace. The revolutionary change from roll to codex, for instance, does not emerge with sufficient clarity; the fact that bookbinding is reserved for another volume leaves a serious gap at this vital point. Certain inconsistencies of arrangement also tend to confuse the reader. For instance, a section on "'The Book' of the Middle Ages" precedes rather than follows Chapter IV, "Greek and Latin Book Production." It also appears that the medieval period as a whole is not covered as thoroughly and as understandingly as the pre-Christian and early Christian developments. Paleography is treated rather superficially and the presentation of the Anglo-Saxon contribution, important as it is, far overshadows continental developments.

In trying to evaluate the effect of these deficiencies it is probably fair to say that The Hand-Produced Book will not lend itself too well to the purposes of a reader who desires a general introduction to the subject, nor, indeed, to text-book needs. Its real value, it seems to me, lies in its vast accumulation of facts, excellently illustrated. It will be a most useful reference work for many years to come. If considered and consulted as a specialized encyclopedia it will prove its unique qualities.

Dr. Richard Mummendey's book, by contrast, is organized as a fairly brief survey and general introduction to the story of books and libraries, mainly in Europe. In the latter portions of this work, dealing with librarianship, German conditions are featured. The illustrations are chosen with care and, again, with special interest in the works of German artists. With some change of emphasis and certain new chapters, including American developments, the book could probably be adapted for the use of students in this country.

Clauss Nissen's work on botanical illustration (reviewed in the July, I952 issue of this journal) has made many friends for its reliable bibliography and the thorough exposi- 
tion of one of the most important branches of the illustration of natural history. Nissen's new work, the Illustrated Bird Books, appears as the first contribution towards a projected record of all zoological illustration. The bibliographical section in the second half of the present volume is a combination of the earlier works of Anker, Zimmer, Coues, Mullens, Swann and Ronsil; as such it will be found a most useful working tool. For the text, in the first half of the volume, the author makes no claim to a $r$ writing of the history of ornithology; rather, he concentrates on its illustration, linking it up in a fresh and penetrating manner with the general history of art and graphic documentation. He pays special attention to the wealth of new studies on the progress of natural representation in the ancient and medieval world and in the early Renaissance. It is here, in the many footnotes quoting publications of recent years, that the reader is impressed with the volume and quality of American scholarship in a field so long dominated by the European specialist.

Although Nissen centers his attention chiefly on the Western tradition, he remains alert to the influence of Asia. $\mathrm{He}$ recognizes in the Near East an important bridge to the ancient world. The importance of the Far East remains enigmatic, since at present we do not know "whether these countries have produced a method of scientific representation similar to ours before their exposure to western science."

The book has 7 line illustrations in the text and 27 illustrations on 16 halftone plates. Especially charming are drawings by a living artist, Franz Murr, who deserves to be better known in these parts. The subdivisions of the text, presented only as running heads, could have been emphasized by a more distinct typographic treatment. Mention should be made of three carefully prepared indices, (I) of artists (with key numbers for draftsmen, engravers, lithographers, photographers, etc.) ; (2) of birds; (3) of countries (chronological lists of the most important publications; and (4) of authors.

By an amusing coincidence Clauss Nissen's bird book, like his work on botanical illustration, appeared practically simultaneously with a book published on the same subject in England. But whereas Wilfrid Blunt's charming and inspiring Art of Botanical Illustration (also reviewed here in the July, I952 issue) was more general and perhaps more popular in appeal than Clauss Nissen's scholarly volume, the current English counter-piece to his Illustrated Bird Books is decidedly a publication of more limited appeal.

The main point of distinction is that the Fine Bird Books addresses itself to the collector rather than to the scholar or bibliographer. Sacheverell Sitwell's introduction is a lively literary essay, with interesting autobiographical notes, rather than an objective history. The years I700-I900 are chosen as the period of the de-luxe publication of folios with magnificent color plates. The present volume recaptures some of their glory in 38 reproductions of which $\mathrm{I} 6$ are in color, selected perhaps rather for their magnificence and splendor than for their artistic accomplishment.

The bibliography is focused upon the "fine" book, "one which is finely produced. Well printed on hand-made paper, preferably finely bound, it should be enjoyable to look at and to handle. The pictures must not only be well drawn but reproduced as near perfect as possible ... the nearer these can be to life size the more agreeable they will be." This latter criterion is a little startling. Poor Thomas Bewick! And a little startling, too, is a merit system of Baedeker stars devised here by a forum which consists of one ornithologist and one bookseller: One star "*" for "fine" books; two stars "**" for "very fine" books; three stars "***" for the finest books. How fine can you get?-Hellmut Lehmann-Haupt, New York.

\section{Foreign Libraries}

Harald Tveterås has succeeded Wilhelm Munthe as director of the University of Oslo
Library. Mr. Tvëteras was formerly one of the head librarians. 